\title{
THE RELATIONSHIPS BETWEEN PLASMA SPECIFIC GRAVITY, PLASMA PROTEIN CONTENT AND EDEMA IN NEPHRITIS
}

\author{
By NORMAN S. MOORE AND DONALD D. VAN SLYKE \\ (From the Hospital of the Rockefeller Institute for Medical Research, New York)
}

(Received for publication July 23, 1929)

In this paper we present data which show (1) a quantitative relationship between plasma pratein content and the tendency to formation of non-cardiac edema in nephritis, (2) demonstrate that the specific gravity of the blood plasma parallels the plasma protein content with sufficient exactness to indicate the level of the latter, and (3) show that the tendency to edema formation is related no less regularly to fall in plasma specific gravity than it is to fall in plasma protein content.

That the concentration of protein in the blood plasma of nephritic patients is low was observed by Bright (1836). Csatáry (1891) noted that the deficiency affected the serum albumin more than it did the globulins, so that the albumin: globulin ratio, normally 1.5 to 2.0 , fell below 1. These observations have been confirmed and amplified by other authors, whose work up to 1923 has been reviewed by Linder, Lundsgaard, and Van Slyke (1924).

Govaerts (1924) has found that the albumin fraction, which suffers as a rule the entire deficit that occurs in the plasma proteins in the nephritic, is osmotically about four times as active per gram as the globulin fraction. Consequently especial interest attaches to determination of not only the total plasma protein content, but also the proportions in it of albumin and globulin. Nevertheless, as we shall show, the tendency to edema, except in rare cases, appears to be correlated about as closely to the total protein as to the albumin fraction, so that as a rule the simpler estimate of total protein content may be used for clinical purposes instead of the more complicated analyses involving separation of the albumin and globulin fractions. 
Because of the importance of plasma protein determinations and the obvious preponderance of the proteins in determining certain of the physical properties of the plasma, repeated attempts have been made to find easily determined measurements of these physical properties to replace chemical analyses for determining the proteins. Starlinger and Hartl (1925) have reviewed methods based on interferometric, polarimetric, viscosimetric, and refractometric measurements, all of which are influenced chiefly by the proteins among plasma constituents.

Of these physical measurements only the refractometric has proved sufficiently practicable to win any general use. It was introduced by Reiss (1904) and Robertson (1915). Neuhausen and Rioch (1923) showed that when proper constants were used it gave good agreement with chemical analyses of normal human plasma. Linder, Lundsgaard, and Van Slyke (1924), however, found refractometric deviations from Kjeldahl results as great as 1.5 grams of protein per $100 \mathrm{cc}$. in normal plasma. Guillaumin, Wahl, and Laurencin (1929) have obtained by the refractometric method similar errors in normal plasma, and much greater ones in plasma of edematous patients. In one case the refractive index indicated over twice as much protein as was present. In this type of pathological plasma, where exact protein values are of most interest, the refractometer suffers the grossest inaccuracies. Presumably this is because the lipoid content is excessive in such plasma, and adds its effect on refractive index to that of the proteins.

In studies of plasma physical characteristics dependent chiefly on the proteins the specific gravity has been comparatively neglected. Butterfield $(1915,1916)$ noted that specific gravity was low in nephritic edema, but not in cardiac edema. Sunderman, Austin, and Camack (1928) have noted, in connection with studies primarily of serum electrolytes, that between refractive-index and specific gravity of serum "the correlation was fair."

\section{TECHNIQUE}

Blood was drawn from a median cubital vein, care being taken that prolonged stasis did not occur in the time between the application of the tourniquet and the insertion of the needle. The blood was at once transferred to a flask containing about $1 \mathrm{mgm}$. of heparin per 
cubic centimeter of blood, and was gently mixed with the heparin to prevent clotting. A glass rod was found to be convenient for this purpose. The flask was then tightly stoppered. The blood was centrifuged, usually within an hour, and clear plasma was obtained. Care was taken in the handling of the plasma both for chemical analysis and for the gravity determination to prevent evaporation. Centrifugation was not unnecessarily prolonged and the tube of plasma was exposed to the air for as short a time as possible.

In determining the specific gravity of the plasma, specific gravity bottles of the common type shown in figure 1 and of approximately 2 cc. capacity, ${ }^{1}$ were used. When such a bottle is filled with solution and closed with a dry glass stopper, slight amounts of fluid, are drawn up by capillary attraction between the stopper and the neck of the flask, and evaporate when they reach the groove at the top of the neck. With the total amount of fluid only $2 \mathrm{cc}$. the loss by this evaporation proved sufficient to cause errors of importance. They were completely prevented, however, by placing a thin film of vaseline about $3 \mathrm{~mm}$. wide around the stopper, as shown in figure 1. Such a band of vaseline added 0.1 to $0.5 \mathrm{mgm}$. to the weight of the bottle. For each determination the bottle, with vaselined stopper, was first weighed empty. It was then filled with plasma at approximately room temperature. A small drop of the plasma pressed out of the capillary in the stopper was left on the latter for 10 or 15 minutes, during which the bottle stood in the balance case to come to its temperature. After this interval the drop was wiped off cleanly, the bottle was wiped with a clean cloth, and was weighed to within $0.1 \mathrm{mgm}$. The specific gravity was calculated as

$$
\text { Specific gravity }=\frac{\text { Weight of plasma held by bottle at } 20^{\circ}}{\text { Weight of water held by bottle at } 20^{\circ}} .
$$

It was found convenient to weigh the filled bottles at room temperature, as above described, and estimate the weight at $20^{\circ}$ by adding or subtracting a correction in milligrams rather than to bring the bottles to $20^{\circ}$ for each weighing. The corrections were obtained by weighing the filled bottles at varying temperatures, and were charted

1 These bottles were made for us by Eimer and Amend of New York. 


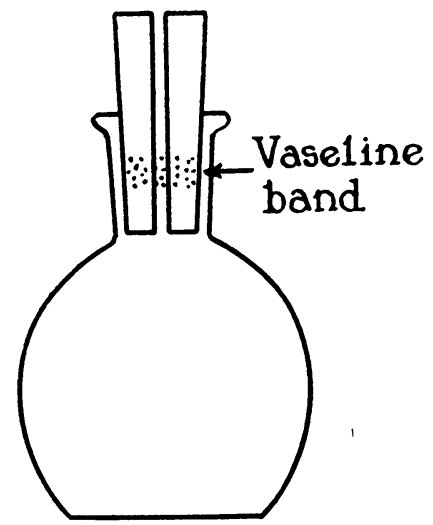

Fig. 1. Type of 2 cc. Specific Gravity Bottle Used, with Band of Vaseline to Prevent Fluid from Creeping up Side of Stopper and Evaporating

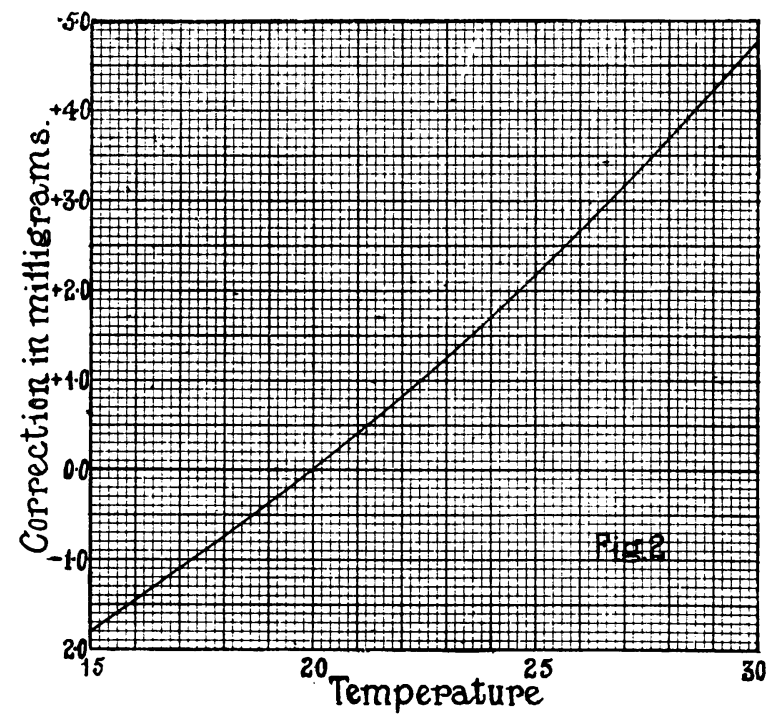

Fig. 2. Corrections to Be Added or Subtracted to Weight of Water or Plasma Observed at Room Temperature in Order to Give Weight which $2 \mathrm{cc}$. Bottle Would Hold at $20^{\circ}$

The correction is added if the temperature is above $20^{\circ}$, subtracted if the temperature is lower. 
as shown in figure 2. The corrections are of course exact only for bottles of $2 \mathrm{cc}$. capacity, but between $15^{\circ}$ and $25^{\circ} \mathrm{C}$. they may be used for bottles of from 1.9 to $2.1 \mathrm{cc}$. For bottles of other sizes the correction varies in proportion to the capacity of the bottle. The correction is added to the observed weight when the temperature is above $20^{\circ}$, subtracted when it is below.

In each plasma the proteins were separated into the albumin and globulin fractions by Howe's method (1921) and determined by Van Slyke's (1927) gasometric micro-Kjeldahl procedure.

TABLE 1

A comparison between the specific gravity of blood plasma of nephritic patients as obtained by weighing and by the time drop method of Barbour

\begin{tabular}{|c|c|c|c|}
\hline Patient & $\mid \begin{array}{c}\text { Specific gravity. } \\
\text { Barbour's time } \\
\text { drop method }\end{array}$ & \begin{tabular}{|} 
Specific gravity. \\
Weighing \\
of the plasma
\end{tabular} & Difference \\
\hline 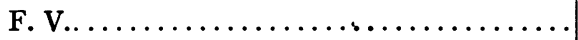 & 1.0258 & 1.0255 & +0.0003 \\
\hline M. M... & 1.0189 & 1.0190 & -0.0001 \\
\hline M. G. $\ldots \ldots \ldots \ldots \ldots \ldots \ldots \ldots$ & 1.0242 & 1.0245 & -0.0002 \\
\hline D. McK......... & 1.0226 & 1.0227 & -0.0001 \\
\hline A. P.............. & 1.0244 & 1.0242 & +0.0002 \\
\hline M. G. $\ldots \ldots \ldots \ldots \ldots \ldots \ldots \ldots \ldots \ldots \ldots$ & 1.0189 & 1.0189 & 0.0000 \\
\hline G. B........ & 1.0236 & 1.0239 & -0.0003 \\
\hline A. C........... & 1.0295 & 1.0292 & +0.0003 \\
\hline Mar.......... & 1.0271 & 1.0270 & +0.0001 \\
\hline C. M. .......... & 1.0239 & 1.0237 & +0.0002 \\
\hline 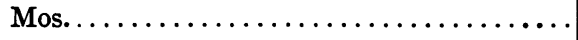 & 1.0283 & 1.0280 & +0.0003 \\
\hline$\ldots \ldots \ldots$ & 1.0282 & 1.0286 & -0.0004 \\
\hline 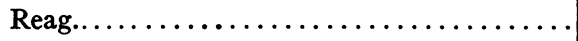 & 1.0244 & 1.0242 & +0.0002 \\
\hline Reich... & 1.0235 & 1.0232 & +0.0003 \\
\hline J. Y............ & 1.0226 & 1.0224 & +0.0002 \\
\hline
\end{tabular}

At the beginning of the study, the specific gravity of the plasma was determined also by Barbour's (1926) method, as well as by the above gravimetric procedure. In Table I are compared the values obtained by the two methods. The agreement between the two sets of values is close. It was felt, however, that the chances of error were greater in Barbour's method because of the precautions required for the keeping of standards, the timing of the drops, and the reading of the nomogram, than the chances of error involved in the gravimetric method. 


\section{RESULTS}

Relationships between protein content and specific gravity

In figure 3 are represented the results of 118 observations on 75 nephritic and 9 normal individuals. Patients suffering from acute and chronic hemorrhagic nephritis and from the degenerative, and arteriosclerotic forms of the disease (in the terminology of Addis (1925)) are included.

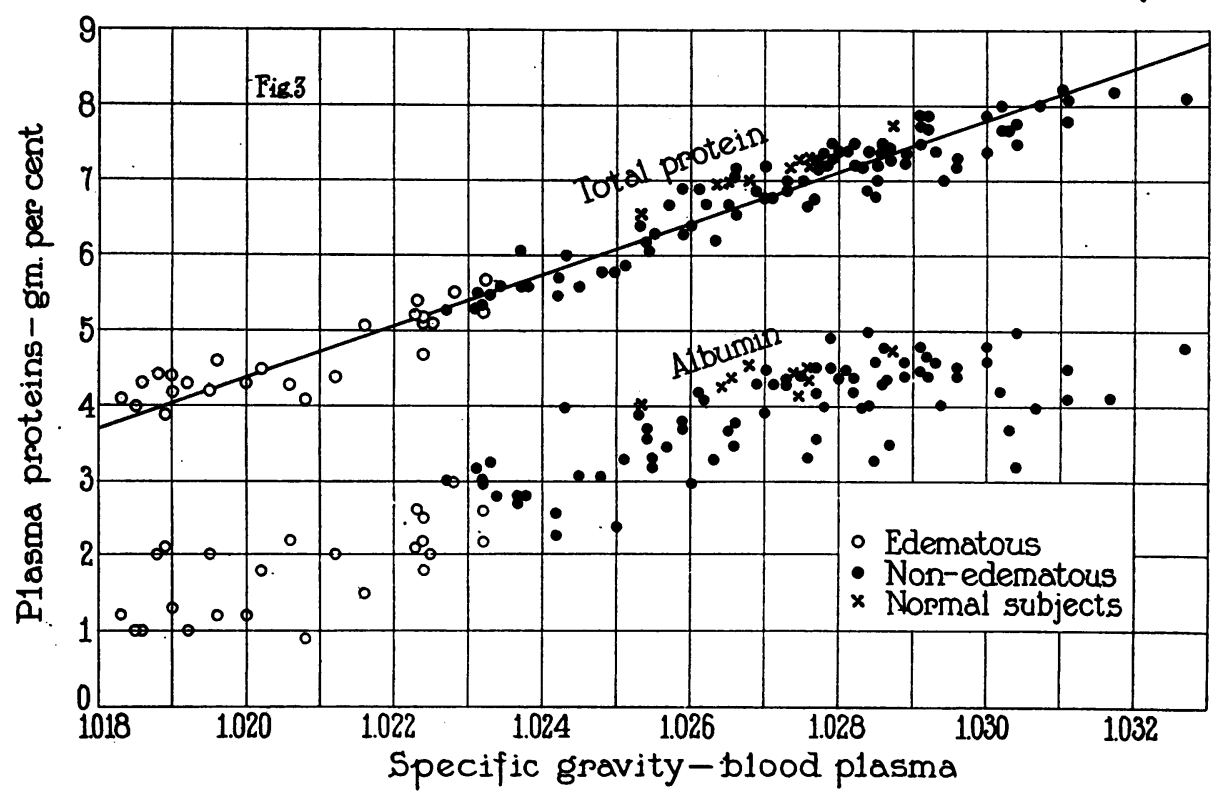

Fig. 3. Relationship of Plasma Specific Gravity to Plasma Protein Content, and of Both to the Presence of Edema in Nephritic

Patients without Cardiac FaILURe

It is obvious from figure 3 that the correlation between specific gravity and the total protein "content of the plasma is fairly close and is a linear function. The total protein content can be most closely calculated from the specific gravity, $G$, by the formula

Grams total protein per $100 \mathrm{cc}$. plasma $=343(G-1.007)$

which is represented by the straight line drawn through the total protein points in figure 3. The maximum deviation of the chemically 
determined protein content from that estimated by the specific gravity is 0.6 gram per $100 \mathrm{cc}$., and the majority of the estimates made from specific gravity are closer. It is evident from comparison of these results with those of the refractometric method quoted in the introduction that in nephritic plasma the protein content is much more closely. correlated to the specific gravity than to the refractive index. Presumably the lipoid content influences the gravity less than it does the refractive index.

The numerical constant 343 indicates that for each increase of 1 gram of protein per $100 \mathrm{cc}$. the specific gravity of the plasma rises by $\frac{1}{343}$ or 0.0029 . With proteins eliminated the gravity of plasma would be 1.007 .

Parts played by globulin and albumin in causing high and low total protein contents

A mean straight line drawn through the albumin points in figure 3 from the points corresponding to a gravity of 1.028 downwards would nearly parallel the line through the total protein points, showing that in Bright's disease protein plasma deficits are due almost entirely to albumin deficits, as has been noted by previous authors.

On the other hand the very high plasma protein contents, somewhat exceeding the usual normal range, observed in some patients, were not accompanied by correspondingly high albumin values. The increases were in the globulin fraction.

In the plasma of the 9 normal subjects the specific gravity varied from 1.0253 to 1.0287 , and averaged 1.027. The total proteins varied from 6.5 to 7.7 per cent, and the albumin from 4.0 to 4.5 . The average was 7.1 per cent total protein, 4.3 per cent albumin, and 2.8 per cent globulin, the corresponding albumin: globulin ratio being therefore 1.53. These protein analyses are in approximate agreement with those of Linder, Lundsgaard, and Van Slyke on 8 normal subjects, their average figures for the 4 above values being $6.73,4.11,2.61$, and 1.57 respectively. Similar results were obtained by Salvesen (1926) in 42 analyses of the plasma of 32 normal men and women. His total proteins were from 6.34 to 7.96 per cent, the average being 7.0, and the average albumin: globulin ratio 1.67 , with variations from 
1.26 to 2.26. These 3 sets of data appear to fix with satisfactory agreement the normal plasma protein values in grams per $100 \mathrm{cc}$. at 6.2 to 8.0 for total protein, of which 3.6 to 5.0 grams are albumin, 2.0 to 3.5 are globulin, the albumin: globulin ratio varying from 1.2 to 2.2 .

\section{Relationship between edema and plasma protein content}

From figure 3 it is evident that none of the patients with total protein content above the critical range $5.5 \pm 0.3$ grams per 100 cc., or albumin content above the range $2.5 \pm 0.2$ grams (with one exception, possibly due to analytical error) showed any edema, while all the patients with total protein and albumin contents below these ranges did show edema detectible by ordinary clinical observation. There was no attempt to correlate degree of edema with degree of plasma protein deficit Such correlation could not be close in hospital patients because the degree of edema that they show is in part dependent upon the length of time they have been upon a régime directed to combat the condition. Although rest in bed, a salt-free diet, and diuretics cause frequently the greater part of edema in a nephritic patient to disappear, it is evident that complete elimination of the fluid is not often attained while the plasma proteins remain below the previously mentioned critical range levels.

Excluded from figure 3 are data only from patients with cardiac decompensation and from one patient, whose data are presented in figure 4, who was in the first month of acute hemorrhagic nephritis. It is well known that the edema of heart failure is not attributable to plasma protein deficit (e.g., see Butterfield, 1916). We have observed also that moderate edema, with puffiness under the eyes, pitting on the body and extremities, but no gross swelling, may occur also in the first weeks of acute hemorrhagic nephritis despite the presence of normal or but slightly diminished total protein and albumin content in the plasma. (E.g., see figure 4 below.) With these exceptions the series in figure 3 represents every nephritic patient on whom observations could be made in the clinic during the period in which our work was carried out.

Epstein (1917) on the basis of Starling's (1895-96) physiological experiments expressed the belief that the relationship between plasma protein deficit and edema in the nephrotic types of Bright's disease 
was one of cause and effect, the edema accumulating in the tissues because the diminished protein osmotic pressure in the circulating plasma was insufficient to hold the fluid within the circulation. In the paper published 6 years ago from this laboratory by Linder, Lundsgaard, and Van Slyke (1924) a conservative attitude was taken towards acceptance of this explanation. Cases were observed in which low plasma proteins were not accompanied by edema. In other cases with low plasma protein content edema was seen to come and go without significant change in the plasma proteins. The existence of a cause and effect relationship between plasma protein deficit and edema formation was accordingly doubted.

In the intervening period, however, continued observations in this laboratory, together with the work of Govaerts (1924) and of Schade and Claussen (1924), have led us to the conclusion that Epstein was right in applying Starling's theory, and that the main and constant factor in producing the tendency towards non-cardiac edema in nephritis is plasma protein deficit.

Obviously this deficit is not the only factor in determining the occurrence and intensity of edema formation. Of other factors the sodium chloride consumption is important. The organism manifests a reluctance to retain water without sufficient salt to form physiological saline solution, and withdrawal of salt from the diet has a great effect in limiting or preventing an edema that would otherwise reach gross proportions. Patients with low plasma proteins, after a prolonged period on a salt-free régime may, either slowly or suddenly, eliminate their surplus fluid and become comparatively, sometimes entirely, edema-free. There is furthermore an unknown physiological factor which, in cases where occurrence or non-occurrence of edema is in the balance, may determine whether edema will occur or not. Thus Linder, Lundsgaard, and Van Slyke (1924) saw edema repeatedly come and go in a patient on an approximately constant hospital régime, without significant accompanying alterations in the plasma protein content. Since their paper appeared other cases in the clinic have shown the same behavior. In such a case, however, the tendency to edema remains until the plasma proteins have risen above the critical level, and edema will return at once if salt is given before the proteins have regained this level. The unknown factor which causes 
variations in edema independent of plasma protein content may be the same which, in its most marked manifestation, causes transient edema formation in the first days of acute nephritis, as illustrated in figure 4. Even in this condition, edema, as in the case reported, is moderate and transient unless plasma protein deficit develops. Such deficit in acute nephritis may develop so rapidly that the plasma proteins fall below the critical level within the first fortnight. It is these cases that present prolonged and intense edema.

The degree of correlation between plasma protein content and edema in the 75 successive patients represented in figure 3 is we believe, evidence in favor of the preponderating influence ordinarily exerted by the plasma proteins in determining the tendency to edema. It has happened that in the series we encountered no cases in which the influence of hospital régime and the unknown physiological factor discussed above interfered with the relationship between edema and plasma protein content to the extent that is occasionally observed; e.g., see figure 6, also certain cases of Linder, Lundsgaard, and Van Slyke (1924). Figure 3 therefore, if considered without regard to other results would give an entirely erroneous idea of absolute regularity of concurrence between existent edema and plasma protein deficit. The fact, however, that in the series observed no exception to the relationship was encountered is, we believe, evidence that such exceptions are rather rare. The relationship of the tendency of plasma

Figs. 4, 5, 6 and 7. Relationship of Plasma Protein Content and Specific Gravity to Edema in 4 Patients Representative of Different Types OF NEPHRITIS

The heavy base lines for the protein and specific gravity values represent the average normal levels found by Salvesen (1926) and the authors respectively for these values. The shaded areas indicate periods during which protein content and specific gravity were below the mean normal levels.

When the space at the bottom of each figure, used to indicate degree of edema, is entirely black, a general edema with ascites is represented. Three-quarters black indicates marked edema, but without severe ascites. Half black represents moderate pitting edema. One-quarter black indicates slight pitting edema.

The small brackets at the right of each figure indicate the critical levels, deduced previously from the data of figure 3. It is seen that when the plasma protein and specific gravity are above these levels edema is absent, and vice versa, except during the first fortnight of the initial acute case represented in figure 4 . 

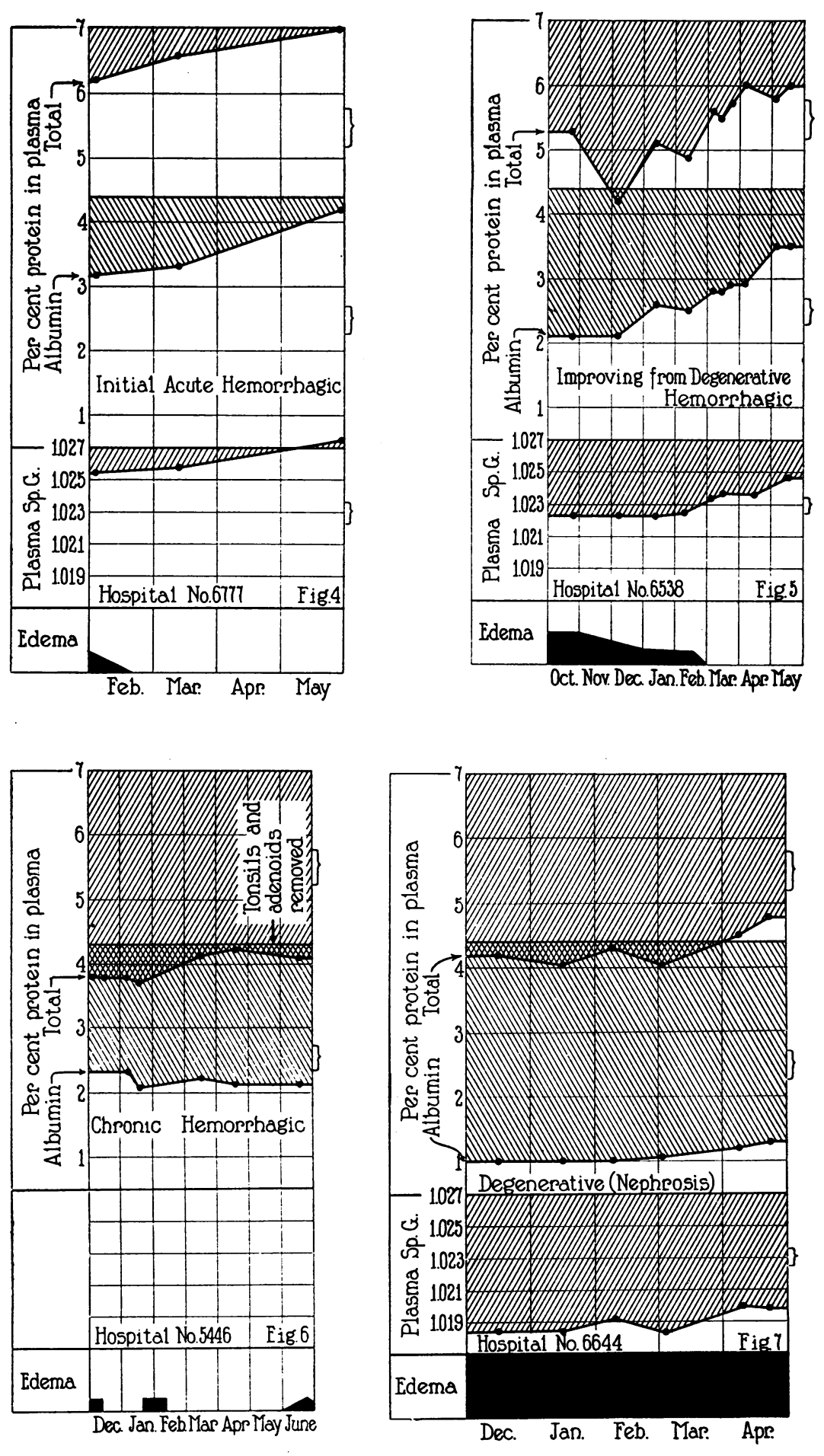
protein content to edema formation is so regular that we have in this clinic come to use the plasma protein content no less than the urea excreting function in diagnosing the potential condition of patients and deciding on therapy. So long as the protein content is below the critical level one can be practically certain that relaxation of salt restriction will be followed by occurrence or increase of edema.

\section{Relationship between edema and plasma specific gravity}

From figure 3 it is evident that none of the patients with plasma specific gravity above the range $1.0230 \pm 0.003$ showed edema, while all with lower specific gravities did. It appears that the tendency to edema formation in nephritis is as closely correlated with the plasma specific gravity as it is with the total protein content determined by Kjeldahl analysis.

\section{Repeated observations in representative cases}

Observations repeated over periods of several months in 4 cases are presented in figures $4,5,6$, and 7 . These cases have been selected because they illustrate the correlation observed between plasma protein content, plasma specific gravity, and edema in the more common types of renal disease. Nephrosclerosis is omitted because it has no characteristic effect on the plasma proteins.

Figure 4 illustrates the occurrence of slight or moderate edema in the first weeks of acute nephritis, despite the fact that plasma protein content and specific gravity are but slightly subnormal and far above the critical levels at which plasma protein deficit of itself appears to produce edema. The patient was a girl of 11 with acute hemorrhagic nephritis following tonsillitis. On admission there was gross hematuria, and the urea excreting power, measured by the blood urea clearance (Möller, McIntosh, and Van Slyke, 1928) was only 6 per cent of normal. There was slight edema over the sternum, sacrum and ankles. Puffiness under eyes was noticeable but not marked. Renal function improved rapidly for 6 weeks, when it came to a standstill with blood urea clearance at about 50 per cent normal. The edema disappeared completely during the first two weeks. During this time, the weight fell 5 kilos, but the loss presumably was in part tissue as well as edema fluid, for the daily food intake then averaged only about 1000 calories, and there was some fever. The patient was discharged after 4 months, subjectively well, but still showing evidence of hemorrhagic nephritis in a latent state. Function was still only $\mathbf{5 0}$ per cent normal; there was a trace of protein in the urine and a slight microscopic hematuria. 
Figure 5 represents observations on a young woman who had suffered an initial attack of acute hemorrhagic nephritis nine months before admission. During the interval she had taken a low protein diet, although there was heavy proteinuria. At the time of admission there was marked pitting edema of the legs. The plasma proteins and plasma specific gravity were low, as seen from figure 5 . For four and a half months the plasma proteins and specific gravity remained low, and the edema continued, although with some diminution, presumably attributable to a rigidly salt-free diet. At the end of this period a definite rise in plasma protein content and gravity occurred to above the critical level, and the edema simultaneously disappeared. The patient was then given a diet containing a few grams of salt daily, without recurrence of edema. A steady rise in plasma protein content and specific gravity continued during the next two months. Neither had quite reached normal at the end of that period, when the patient was discharged.

Figure 6 shows data from a case of chronic hemorrhagic nephritis that was observed before we began to take plasma specific gravities, but that we have selected because it illustrates the interference of three different factors with the relationship between plasma protein content and edema. The plasma albumin remained persistently just below the critical level, and edema was present or absent according to the influence exerted by other factors. This case is exceptional in that the globulins were persistently low. In consequence, the total proteins were always below 4 per cent, the same as in figure 7 . But in the present case there was more than 2.2 per cent of albumin, while in the case of figure 7 albumin was only 1 per cent. The relative tendencies to edema accord with Govaerts' conception that the albumin, because of its 4 -fold greater osmotic pressure per gram, is the chief factor in preventing edema. The case in figure 7 , with 1 per cent albumin, presented continual, obstinate, generalized gross edema and ascites, while the case in figure 6 , with 2.2 per cent albumin, was readily rendered edema-free by rest in bed and salt-free diet.

The patient, a man of 25 , had developed edema and dyspnea after a severe cold 5 months before admission. One month later tonsillectomy was performed.

On admission there was no dyspnea. There was marked microscopic hematuria, and heavy proteinuria. The urine sediment also contained leucocytes, hyaline and granular casts, and doubly refractive bodies. The eye-grounds were normal. Blood pressure was about $150 / 80$. The heart was somewhat enlarged. The patient had been on moderate salt restriction at home, and was excreting 2 to 4 grams of $\mathrm{NaCl}$ per 24 hours. There was edema of the legs. The renal function, measured by the blood urea clearance, was 40 per cent of normal.

In two weeks under hospital regime the edema disappeared and the patient lost 3 kilos of weight. With a salt restricted regime, limiting $\mathrm{NaCl}$ output to about 1 gram per 24 hours, edema remained absent.

From January 23 to 25 inclusive, 3.5 grams of $\mathrm{NaCl}$ per day were added to the diet, and from January 25 to February 2 inclusive, 6.5 grams. On January 28 the weight had gone up 2 kilos and there was a trace of edema about the sacrum. 
By February 3 the weight had gone up another kilo, and there was edema about the sacrum and in the legs. Salt was removed from the diet and the edema had disappeared by February 11.

Edema then remained absent until after a second tonsillectomy on May 21. Some days later puffiness of the face was apparent, and pitting edema of the leg. During three weeks after the tonsillectomy body weight increased 3 kilos. Then the edema subsided and the excess weight disappeared.

During the 6 months observation the blood urea clearance gradually declined to 25 per cent of normal.

This case illustrates the following factors than can interfere with the usual quantitative relationship between edema and plasma protein deficit in nephritis:

1. Abnormal globulin, as well as albumin content. The globulin is so low that it makes the total proteins much lower than they ordinarily would be with the same albumin deficit. The tendency to edema follows the total protein deficit chiefly because the latter reflects albumin deficit. In this case the total deficit represents the sum of albumin deficit and globulin deficit, and is consequently out of proportion to the former, and to the tendency towards edema, which is not very great.

2. Salt intake. The disappearance of edema after admission, its reappearance in January after salt was added to the diet, its disappearance again as soon as salt was once more restricted, illustrate this influence in a case with plasma albumin just below the critical level.

3. Toxic injury. Following tonsillectomy in May transitory edema occurred, despite continued salt restriction, and without change in plasma protein content. This edema in its behavior is similar to that of the edema encountered in the initial acute stage of hemorrhagic nephritis.

Figure 7 shows typical observations on a patient suffering from a severe form of non-hemorrhagic degenerative Bright's disease (nephrosis). Ascites, gross anasarca, and generalized edema were present for three months before admission. On admission the patient weighed over 100 kilos, about one-third of his weight being apparently edema fluid. The daily protein output in the urine was 20 to 30 grams. The total protein content of the plasma was less than the normal albumin content, and, as seen from figure 7 , the plasma albumin was reduced to 1 gram per $100 \mathrm{cc}$. The specific gravity showed a corresponding reduction to 

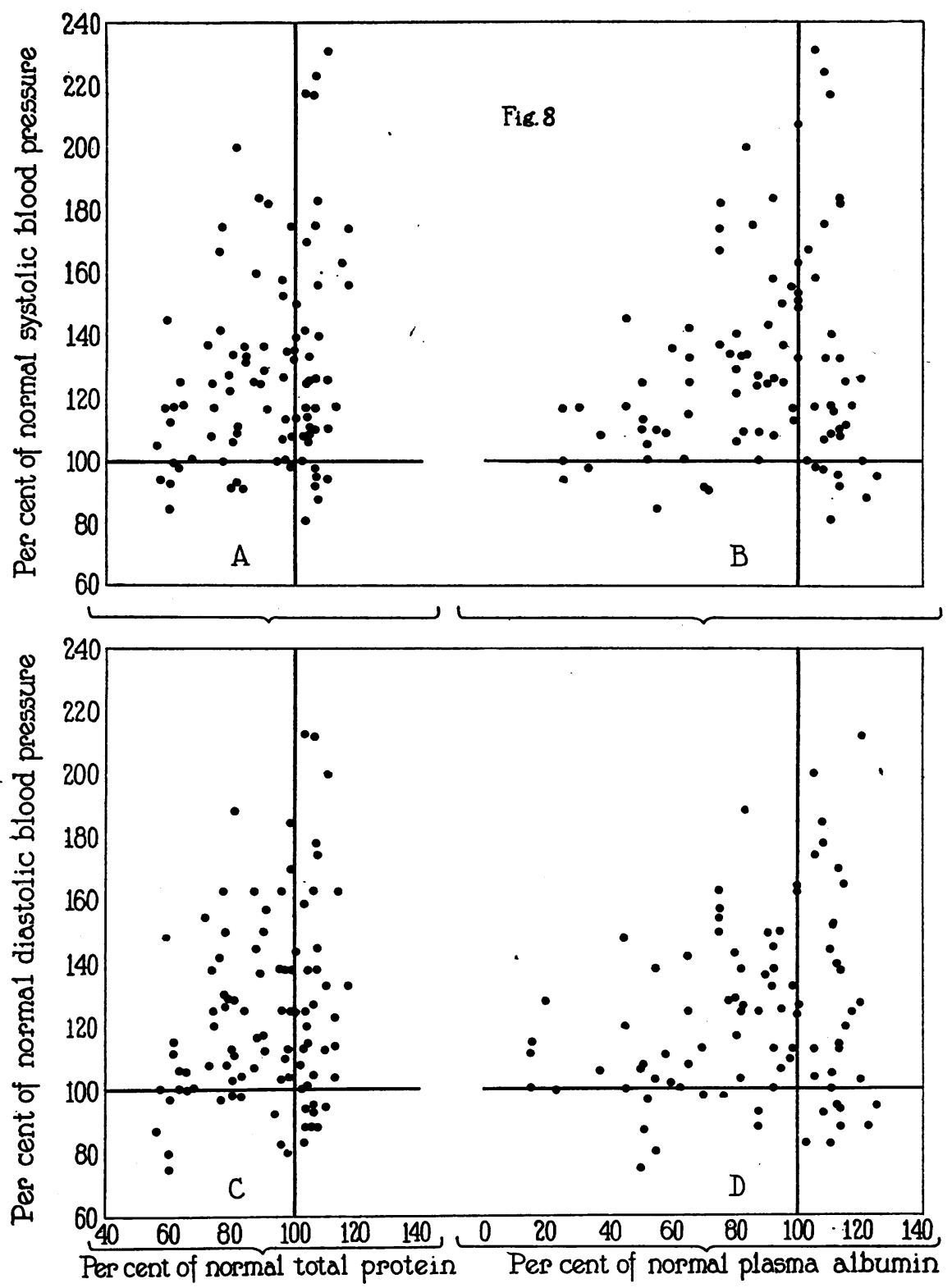

Fig. 8. Absence of Relationship between Blood Pressure and Plasma Protein Content in Nephritis 
1.0186. During the 5 months in which the patient was under observation the plasma proteins and specific gravity remained very low and the edema extensive, although some 20 kilos were eliminated is the apparent result of a strictly saltfree regime, urea administration, and treatment with thyroid.

\section{Lack of relation between plasma protein content and blood pressure}

Govaerts (1924) has pointed out the fact that in a proportion of cases with simple hypertension the plasma protein content is above the normal range, and has discussed briefly the possible significance of such a relationship. In order to ascertain whether in nephritis there is any correlation between plasma protein content and blood pressure we have in figure 7 compared the two sets of values in the patients reported in figure 3. The series includes patients ranging in age from 3 years to 65 . Measurements of blood pressure were taken usually on the day the blood was drawn for analysis, although in a few instances they were taken a day or two earlier or later. Using as base lines 7 per cent as the normal value for total protein and 4 per cent as that for albumin, the percentages of these values found are plotted in figure 8 against percentages of mean normal systolic and diastolic pressure. The mean normal values for the pressures of subjects under 16 'years of age are taken from Faber's (1921) tables. For subjects above that age $120 \mathrm{~mm}$. of mercury was taken as the normal systolic level and $80 \mathrm{~mm}$. as the diastolic level (Alvarez, 1920).

These results in figure 8 indicate but little relationship between plasma protein content and blood pressure. The only relationship that is visible is that very high blood pressures, over 160 per cent of mean normal, do not accompany very low plasma total protein or albumin, less than 60 per cent of mean normal. Except for this slight relationship, all concentrations of plasma proteins were observed at all levels of systolic and diastolic blood pressure. Our observations on the protein content of the plasma and blood pressure are comparable to those of Cope (1928) on the osmotic pressure of the plasma proteins and blood pressure, with the exception that in our cases we frequently observed hypertension associated with considerable diminution of the plasma proteins. 


\section{SUMMARY}

There is a linear relationship between plasma specific gravity and total protein content which holds for blood from both normal and nephritis subjects. Normal plasma with 7 grams of protein per $100 \mathrm{cc}$. has a specific gravity of approximately 1.027 , the gravity of water at the same temperature being taken as 1.000 . With each increase or decrease of 1 gram of protein the gravity rises or falls 0.0029 .

The relationship between gravity and protein content in nephritic plasma is much closer than that between refractive index and protein content.

The presence of non-cardiac edema in most cases of nephritis is closely related to the decrease in total protein content and specific gravity of the plasma. In the 75 patients examined, who included hemorrhagic, degenerative, and arteriosclerotic types of renal disease, it was found that when the total protein content fell below the lower limit of the range $5.5 \pm 0.3$ per cent, or the albumin below $2.5 \pm 0.2$ per cent, or the specific gravity below $1.0230 \pm 0.0003$, edema was usually present. When the protein content and gravity were above the upper limits of these ranges edema was usually absent.

Exceptions to the usual relationship between plasma protein deficit and edema have been met as follows: (1) During the first weeks of acute hemorrhagic nephritis, and during exacerbations of hemorrhagic nephritis caused by injury or infection, a transient edema may occur when plasma proteins, both total and albumin are above the critical levels mentioned in the preceding paragraph. (2) When the plasma globulin content is affected, so that the total protein changes do not parallel albumin changes, total protein content and specific gravity also lose their relationship to edema, the tendency to which appears dependent on albumin rather than on globulin deficit. (3) Salt restriction may cause edema to disappear when total plasma protein and albumin are below the critical levels. Usually, however, when the proteins are below the critical level salt restriction causes only partial disappearance of edema.

\section{BIBLIOGRAPHY}

Addis, T., J. Am. Med. Assoc., 1925, lxxxv, 163. A Clinical Classification of Bright's Disease. 
Alvarez, W. C., Arch. Int. Med., 1920, xxvi, 381. Blood Pressure in University Freshmen and Office Patients.

Barbour, H. G., and Hamilton, W. F., J. Biol. Chem., 1926, lxix, 625. The Falling Drop Method for Determining Specific Gravity.

Bright, Richard, Guy's Hospital Reports, 1836, i, 338. Cases and Observations Illustrative of Renal Disease Accompanied with the Secretion of Albuminous Urine.

Butterfield, E. E., and Braddock, W. H., Proc. Soc. Exp. Biol. and Med., 1915, xii, 73. Physical Analysis of Blood Serum in Nephropathies and Cardiopathies.

Butterfield, E. E., Erdwurm, F., and Braddock, W. H., Am. J. Med. Sci., 1916, cli, 63. Differentiation of Nephropathies, Cardiopathies, and Allied Conditions.

Cope, C. L., Quart. J. Med., 1928, xxii, 91. The Osmotic Pressure of the Blood Proteins in Nephritis.

Csatáry, A., Deutsch. Arch. klin. Med., 1891, xlviii, 358. Ueber Globulinurie. II.

Epstein, A. A., Am. J. Med. Sci., 1917, cliv, 638. Concerning the Causation of Edema in Chronic Parenchymatous Nephritis. Method for Its Alleviation.

Faber, H. K., and James, C. A., Am. J. Dis. Child., 1921, xxii, 7. The Range and Distribution of Blood Pressures in Normal Children. Clinical Application of Statistical Methods to the Interpretation of Deviation from the Normal Average.

Govaerts, P., Bull. d. l'Académie Roy. d. Méd. d. Beligique., 1924, iv, 161. Recherches cliniques sur le rôle de la pression osmotique des protéines du sang, dans la pathogénie des oedèmes et de l'hypertension artérielle.

Guillaumin, Ch. O., Wahl, R., and Laurencin, M. L., Bull. d. l. Soc. Chim. Biol., 1929, xi, 387. Sur le dosage des albumines sériques. Comparaison de quelques résultats obtenus par pesée, par azotométrie et par réfractometrie.

Howe, P. E., J. Biol. Chem., 1921, xlix, 109. The Determination of Proteins in Blood-a Micro Method.

Linder , G. C., Lundsgaard, C., and Van Slyke, D. D., J. Exp. Med., 1924, xxxix, 887. The Concentration of the Plasma Proteins in Nephritis.

Möller, E., McIntosh, J. F. and Van Slyke, D. D., J. Clin. Invest., 1928, vi, 427. Studies of Urea Excretion. II. Relationship between Urine Volume and the Rate of Urea Excretion by Normal Adults.

Neuhausen, B. S., and Rioch, D. M., J. Biol. Chem., 1923, lv, $353 . \quad$ The Refractometric Determination of Serum Proteins.

Reiss, E., Beitr. z. chem. Physiol. u. Path., 1903, iv, 150. Der Brechungskoeffizient der Eiweisskörper des Blutserums. Arch. f. exp. Path. u. Pharm., 1904, li, 18. Eine neue methode der quantitativen Eiweiss Bestimmung.

Robertson, T. B., J. Biol. Chem., 1915, xxii, 233. A Micro-refractometric Method of Determining the Percentages of Globulin and Albumin in Very Small Quantities of Blood Serum. 
Salvesen, H. A., Acta. Med. Scand., 1926, lxv, 147. Plasma Proteins in Normal Individuals.

Schade, H., and Claussen, F., Ztschr. f. klin. Med., 1924, c, 363. Der onkotische Druck des Blutplasmas und die Entstehung der renal bedingten Ödeme.

Starling, E. H. J., Physiol., 1895-6, xix, 312. On the Absorption of Fluids from the Connective Tissue Spaces.

Starlinger, W., and Hartl, K., Biochem. Z., 1925, clvii, 283; 1925, clx, 113. Ueber die Methodik der quantitativen Bestimmung des Fibrinogens. III. Bestimmung der Eiweisskörper gruppen des menschlichen Blutserums. I. Uther die Methodik der quantitativen.

Sunderman, F. W., Austin, J. H., and Camack, J. G., J. Clin. Invest., 1928, vi, 37. Studies of Serum Electrolytes. III. In Infections, Nephritis, and Other Pathological Conditions.

Van Slyke, D. D., J. Biol. Chem., 1927, lxxi, 235. Gasometric Micro-Kjeldahl Determination of Nitrogen. 